\title{
Gas phase acid, ammonia and aerosol ionic and trace element concentrations at Cape Verde during the Reactive Halogens in the Marine Boundary Layer (RHaMBLe) 2007 intensive sampling period
}

\author{
R. Sander ${ }^{1}$, A. A. P. Pszenny ${ }^{2}$, W. C. Keene ${ }^{3}$, E. Crete ${ }^{2, *}$, B. Deegan ${ }^{4, * *}$, M. S. Long ${ }^{3, * * *}$, J. R. Maben ${ }^{3}$, and \\ A. H. Young ${ }^{2}$ \\ ${ }^{1}$ Air Chemistry Department, Max-Planck Institute of Chemistry, P.O. Box 3060, 55020 Mainz, Germany \\ ${ }^{2}$ University of New Hampshire, Durham, NH, USA \\ ${ }^{3}$ Department of Environmental Sciences, University of Virginia, Charlottesville, VA 22904, USA \\ ${ }^{4}$ Mount Washington Observatory, North Conway, New Hampshire, USA \\ *now at: The Earth Institute, Columbia University, NY, USA \\ ** now at: 97 Raymond St., Fairhaven, MA, USA \\ *** now at: Harvard University, Cambridge, MA, USA \\ Correspondence to: R. Sander (rolf.sander@mpic.de)
}

\begin{abstract}
Received: 28 June 2013 - Published in Earth Syst. Sci. Data Discuss.: 29 July 2013
Revised: 27 November 2013 - Accepted: 4 December 2013 - Published: 20 December 2013
\end{abstract}

\begin{abstract}
We report mixing ratios of soluble reactive trace gases sampled with mist chambers and the chemical composition of bulk aerosol and volatile inorganic bromine $\left(\mathrm{Br}_{\mathrm{g}}\right)$ sampled with filter packs during the Reactive Halogens in the Marine Boundary Layer (RHaMBLe) field campaign at the Cape Verde Atmospheric Observatory (CVAO) on São Vicente island in the tropical North Atlantic in May and June 2007. The gas-phase data include $\mathrm{HCl}, \mathrm{HNO}_{3}, \mathrm{HONO}, \mathrm{HCOOH}, \mathrm{CH}_{3} \mathrm{COOH}, \mathrm{NH}_{3}$, and volatile reactive chlorine other than $\mathrm{HCl}$ $\left(\mathrm{Cl}^{*}\right)$. Aerosol samples were analyzed by neutron activation $(\mathrm{Na}, \mathrm{Al}, \mathrm{Cl}, \mathrm{V}, \mathrm{Mn}$, and $\mathrm{Br})$ and ion chromatography $\left(\mathrm{SO}_{4}^{2-}, \mathrm{Cl}^{-}, \mathrm{Br}^{-}, \mathrm{NH}_{4}^{+}, \mathrm{Na}^{+}, \mathrm{K}^{+}, \mathrm{Mg}^{2+}\right.$, and $\left.\mathrm{Ca}^{2+}\right)$. Content and quality of the data, which are available under doi:10.5281/zenodo.6956, are presented and discussed.
\end{abstract}

\section{Introduction}

Multiphase halogen chemistry impacts important, interrelated chemical processes in marine air. Bromine activation chemistry leads to catalytic ozone destruction and modification of oxidation processes including $\mathrm{HO}_{\mathrm{x}}$ and $\mathrm{NO}_{\mathrm{x}}$ cycling. Spatiotemporal variability in many reactants, products and reaction pathways are poorly characterized, rendering uncertain the global significance of tropospheric halogen chemistry.

\section{Data set description and access}

RHaMBLe was a large-scale investigation of reactive halogen cycling and associated impacts on oxidation processes in the marine boundary layer over the eastern North Atlantic Ocean (Lee et al., 2010). As part of RHaMBLe, (Reactive Halogens in the Marine Boundary Layer) an intensive 25 day process study was conducted during spring 2007 at the Cape Verde Atmospheric Observatory (Fig. 1) on the windward shore of São Vicente Island $\left(16.8^{\circ} \mathrm{N}, 24.9^{\circ} \mathrm{W}\right)$ in the tropical, eastern North Atlantic (Fig. 2). Data from this field intensive campaign coupled with measurements within the surrounding region and at the observatory during other periods have been used to address a range of topics including 


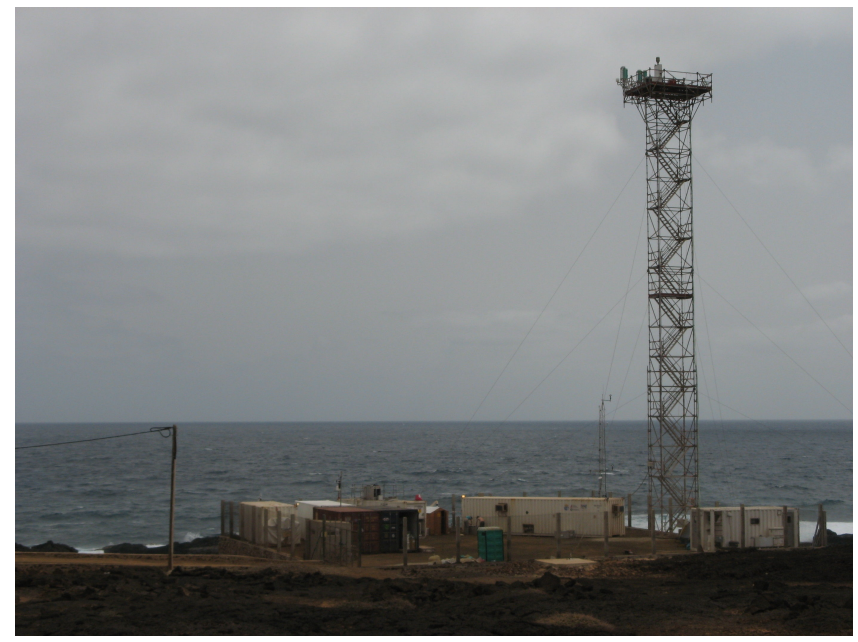

Figure 1. The sampling tower at the Cape Verde Atmospheric Observatory in 2007.
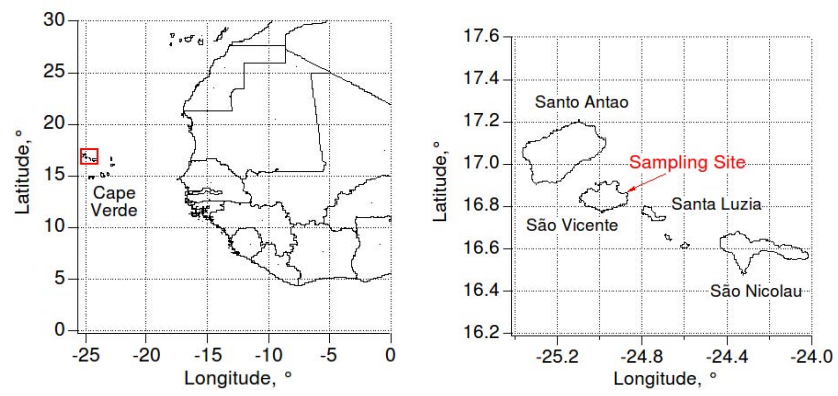

Figure 2. Location of the sampling site.

halogen-mediated destruction of ozone (Read et al., 2008), pollution-enhanced production of $\mathrm{Cl}$ radicals and associated influences on oxidation processes (Lawler et al., 2009), the cycling of reactive nitrogen oxides (Lee et al., 2009), and the composition and processing of aerosols (Allan et al., 2009), among others. Herein, we report a suite of soluble reactive trace gases, volatile inorganic bromine, and ionic and elemental aerosol constituents measured from the top of the observatory's $30 \mathrm{~m}$ tower during the RHaMBLe campaign.

The complete data set is available in NASA Ames format $^{1}$ from the Zenodo repository service under doi:10.5281/zenodo.6956. In addition, we also provide comma-separated-values (csv) files of the full data set in the Supplement.

\section{Instruments and methods}

All air volumes reported here are normalized to standard temperature and pressure $\left(273 \mathrm{~K}\right.$ and $\left.1.013 \times 10^{5} \mathrm{~Pa}\right)$.

\footnotetext{
${ }^{1}$ http://badc.nerc.ac.uk/help/formats/NASA-Ames
}

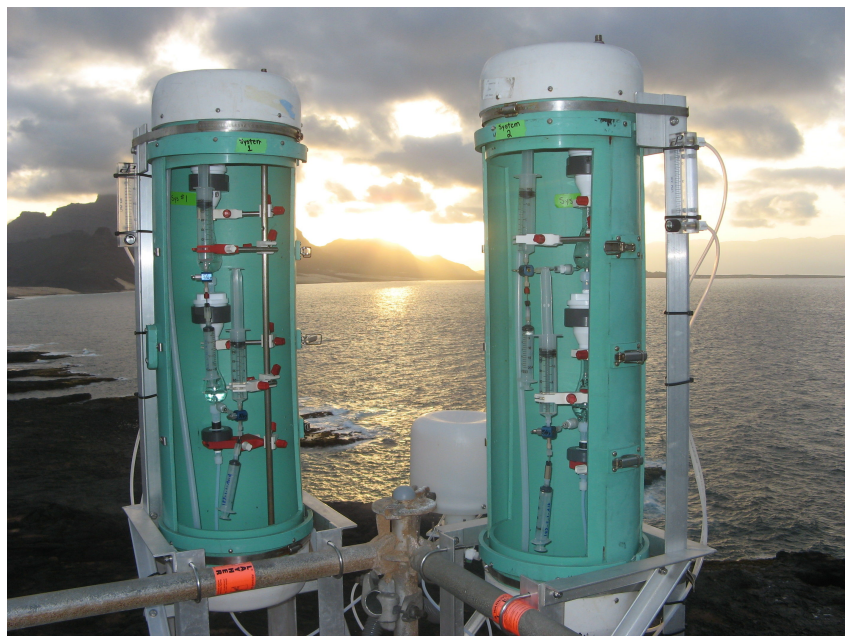

Figure 3. Mist chambers at the Cape Verde sampling tower.

\subsection{Mist chambers}

Water-soluble, volatile inorganic chlorine and nitrate (dominated by and hereafter referred to as $\mathrm{HCl}$ and $\mathrm{HNO}_{3}$, respectively), $\mathrm{NH}_{3}, \mathrm{HCOOH}$, and $\mathrm{CH}_{3} \mathrm{COOH}$ were sampled over $2 \mathrm{~h}$ intervals at nominal flow rates of $20 \mathrm{~L} \mathrm{~min}^{-1}$ with a single set of tandem mist chambers (Figs. 3, 4), each of which contained $20 \mathrm{~mL}$ deionized water (Lawler et al., 2009). To minimize artifact phase changes caused by mixing chemically distinct aerosol size fractions on bulk prefilters, air was sampled through a size-fractionating inlet that inertially removed super- $\mu \mathrm{m}$ aerosols from the sample stream. Sub$\mu \mathrm{m}$ aerosol was removed downstream by an in-line $47 \mathrm{~mm}$ Teflon filter (Zefluor $2 \mu \mathrm{m}$ pore diameter). In-line filters were changed daily. Samples were analyzed on site by ion chromatography (IC) usually within a few hours after recovery. Data were corrected based on dynamic handling blanks that were loaded, briefly (few seconds) exposed to ambient air flow, recovered, processed, and analyzed using procedures identical to those for samples. Collection efficiencies for all species were greater than $95 \%$ and, consequently, corrections for inefficient sampling were not necessary. Detection limits (DLs; estimated following Keene et al., 1989) for $\mathrm{HCl}$, $\mathrm{HNO}_{3}, \mathrm{NH}_{3}, \mathrm{HCOOH}$, and $\mathrm{CH}_{3} \mathrm{COOH}$ were 26, 12, 3, 29, and $44 \mathrm{pmolmol}^{-1}$, respectively. The corresponding precision for each analyte is approximately one half of the estimated DL.

Reactive inorganic chlorine gases $\left(\mathrm{Cl}^{*}\right)$ were sampled in parallel through an identical inlet with similar sets of tandem mist chamber samplers (Keene et al., 1993; Maben et al., 1995; Lawler et al., 2009). The upstream chamber contained acidic solution $\left(37.5 \mathrm{mM} \mathrm{H}_{2} \mathrm{SO}_{4}\right.$ and $\left.0.042 \mathrm{mM}\left(\mathrm{NH}_{4}\right)_{2} \mathrm{SO}_{4}\right)$, which removed $\mathrm{HCl}$ quantitatively but efficiently passed other forms of volatile $\mathrm{Cl}$, and the downstream chamber contained alkaline solution $(30.0 \mathrm{mM} \mathrm{NaHCO} 3$ and $0.408 \mathrm{mM}$ $\mathrm{NaHSO}_{3}$ ), which sampled $\mathrm{Cl}^{*}$ (including $\mathrm{Cl}_{2} \mathrm{HOCl}$, and 


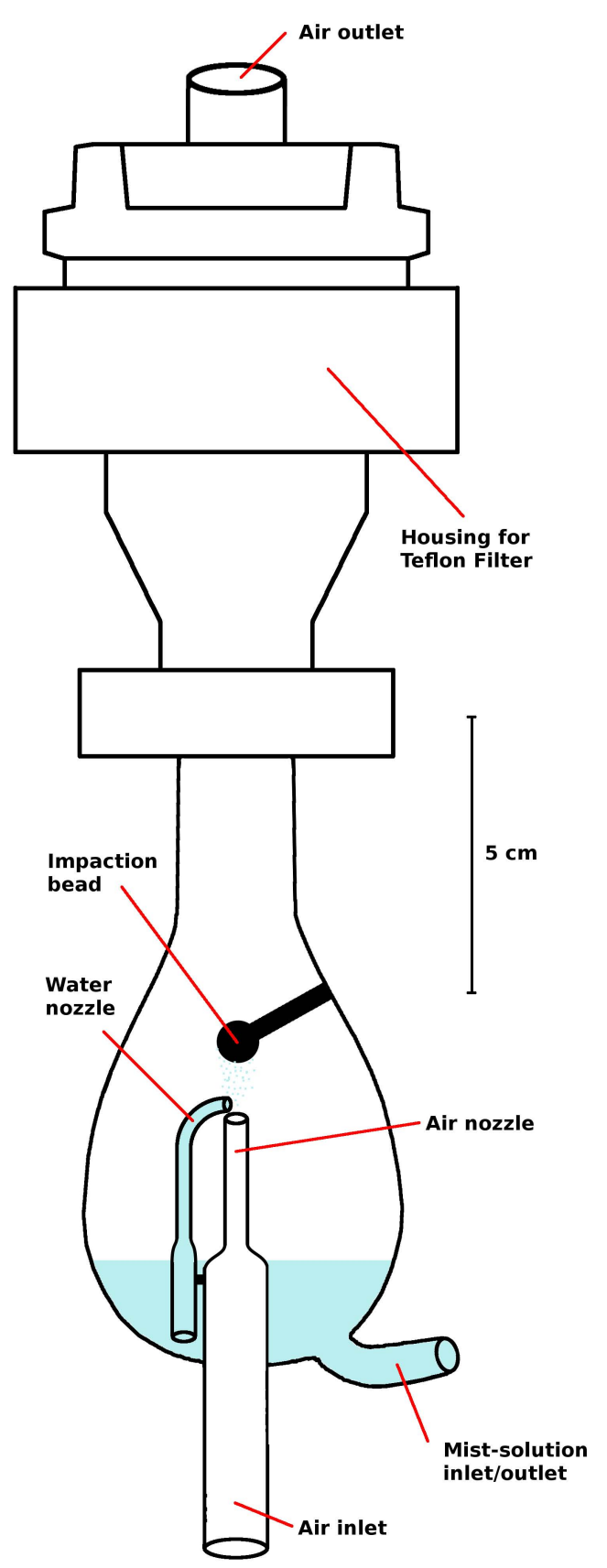

Figure 4. Schematic of a mist chamber (to scale). The teflon filter (only housing is shown) serves as a liquid barrier.

probably contributions from $\mathrm{ClNO}_{3}, \mathrm{ClNO}_{2}, \mathrm{BrCl}, \mathrm{ClO}$, and $\mathrm{Cl}$ ). Available evidence (Keene et al., 1993; Maben et al., 1995) indicates that this sampling technique reliably discriminates volatile inorganic $\mathrm{Cl}$ from $\mathrm{Cl}$ associated with both particles and organic gases and that it quantitatively differentiates between $\mathrm{HCl}$ and other forms of volatile inorganic $\mathrm{Cl}$. However, the speciation of $\mathrm{Cl}^{*}$ cannot be determined unequivocally. Mist solutions were analyzed on site by IC.

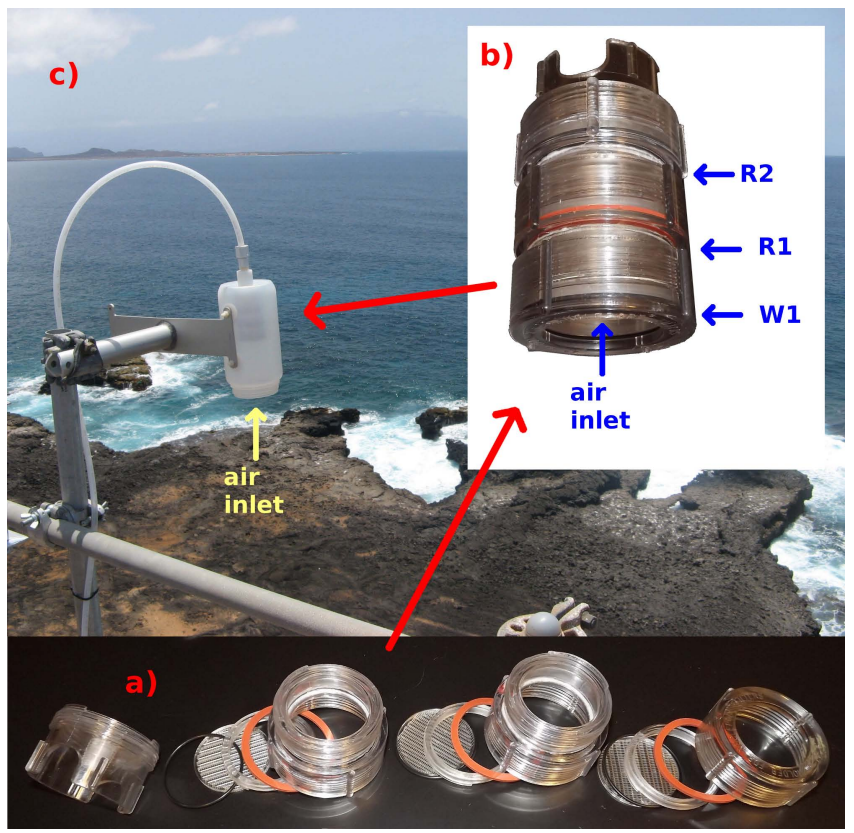

Figure 5. Filter packs: (a) individual pieces (without filters); (b) assembled filter pack with positions of the Whatman (W1) and Rayon (R1, R2) filters indicated; (c) deployment at the Cape Verde sampling tower.

The average precision for $\mathrm{Cl}^{*}$ was approximately $\pm 15 \%$ or $\pm 7 \mathrm{pmol} \mathrm{mol}^{-1} \mathrm{Cl}$, whichever was the greater absolute value, and the corresponding average DL based on Keene et al. (1989) was $14 \mathrm{pmol} \mathrm{mol}^{-1} \mathrm{Cl}$.

\subsection{Filter-pack sampling and chemical analysis}

Using a modification of the technique by Rahn et al. (1976), total aerosol and inorganic gases were sampled using filter packs with 3 filters (Fig. 5). Particles were sampled on dry $47 \mathrm{~mm}$ diameter Whatman 41 cellulose filters that were positioned upstream (W1 in Fig. 5). Each filter was precleaned with deionized water (DIW) and dried prior to the campaign. Alkaline-reactive trace gases were sampled on moist tandem Rayon filters (SKU 64007, Leader Evaporator), impregnated with an alkaline solution $(10 \mathrm{~g} \mathrm{LiOH}$ and $10 \mathrm{~mL}$ glycerol per $100 \mathrm{~mL}$ ), positioned in tandem downstream (R1 and R2 in Fig. 5). Filters from the same lot were used for all samples, blanks, and analytical standards. Sample and field blank filters were mounted in $47 \mathrm{~mm}$ diameter Nuclepore polycarbonate cassettes. Seven samples were collected each day with sample changes keyed to sunrise and sunset and other change times adjusted such that sampling interval durations were similar ( 3 to $4 \mathrm{~h}$ ). The airflow was about 80 standard liters per minute (SLPM) and monitored with a mass flow meter. Field blanks were obtained once per day at different times. Each field blank was loaded, deployed, exposed briefly (few seconds) to ambient air, recovered, processed, 
Table 1. Data summary. Here, DL is the detection limit. $N($ tot $)$ and $N(<\mathrm{DL})$ are the total number of data points and the number below the DL, respectively.

\begin{tabular}{|c|c|c|c|c|c|c|c|}
\hline & minimum & maximum & median & $\mathrm{DL}^{*}$ & $N($ tot $)$ & $N(<\mathrm{DL})$ & unit \\
\hline \multicolumn{8}{|c|}{ mist chamber } \\
\hline $\mathrm{HCl}$ & $<\mathrm{DL}$ & 613 & 206 & 26 & 212 & 13 & $\mathrm{pmol} \mathrm{mol}^{-1}$ \\
\hline $\mathrm{Cl}^{*}$ & $<\mathrm{DL}$ & 222 & 21 & 14 & 212 & 79 & pmol mol $^{-1}$ \\
\hline $\mathrm{HNO}_{3}$ & $<\mathrm{DL}$ & 124 & 14 & 12 & 212 & 90 & pmol mol $^{-1}$ \\
\hline $\mathrm{NH}_{3}$ & $<\mathrm{DL}$ & 651 & 18 & 3 & 212 & 51 & $\mathrm{pmol} \mathrm{mol}^{-1}$ \\
\hline $\mathrm{HCOOH}$ & $<\mathrm{DL}$ & 796 & 128 & 29 & 212 & 68 & $\mathrm{pmol} \mathrm{mol}^{-1}$ \\
\hline $\mathrm{CH}_{3} \mathrm{COOH}$ & $<\mathrm{DL}$ & 550 & 78 & 44 & 212 & 68 & $\mathrm{pmol} \mathrm{mol}^{-1}$ \\
\hline \multicolumn{8}{|c|}{ filter pack (NAA) } \\
\hline $\mathrm{Na}$ & 1.12 & 7.69 & 3.3 & 0.031 & 147 & 0 & $\mu \mathrm{g} \mathrm{m}^{-3}$ \\
\hline $\mathrm{Al}$ & $<\mathrm{DL}$ & 0.559 & 0.095 & 0.013 & 147 & 2 & $\mu \mathrm{g} \mathrm{m}^{-3}$ \\
\hline $\mathrm{Cl}$ & 0.39 & 6.84 & 2.6 & $0.079,0.13$ & 147 & 0 & $\mu \mathrm{g} \mathrm{m}^{-3}$ \\
\hline $\mathrm{EF}(\mathrm{Cl})$ & 0.194 & 0.752 & 0.432 & & 147 & & \\
\hline $\mathrm{Cl}$ deficit & 1.21 & 6.96 & 3.17 & & 147 & & $\mu \mathrm{g} \mathrm{m}^{-3}$ \\
\hline $\mathrm{V}$ & $<\mathrm{DL}$ & 2.21 & 0.68 & 0.26 & 147 & 16 & $\mathrm{ng} \mathrm{m}^{-3}$ \\
\hline $\mathrm{Mn}$ & $<\mathrm{DL}$ & 4.98 & 1.12 & 0.52 & 147 & 17 & $\mathrm{ng} \mathrm{m}^{-3}$ \\
\hline $\mathrm{Br}$ & $<\mathrm{DL}$ & 26.3 & 8.39 & 4.2 & 147 & 35 & $\mathrm{ng} \mathrm{m}^{-3}$ \\
\hline $\mathrm{EF}(\mathrm{Br})$ & 0.0524 & 1.06 & 0.392 & & 147 & & \\
\hline Br deficit & -1.33 & 36.7 & 11.3 & & 147 & & $\mathrm{ng} \mathrm{m}^{-3}$ \\
\hline $\mathrm{Br}_{\mathrm{g}}$ & 3.26 & 41.7 & 16.8 & & 147 & & $\mathrm{ng} \mathrm{m}^{-3}$ \\
\hline$\Delta \mathrm{Br}$ & -20.8 & 29.2 & 5.48 & & 147 & & $\mathrm{ng} \mathrm{m}^{-3}$ \\
\hline \multicolumn{8}{|c|}{ filter pack (IC) } \\
\hline $\mathrm{Cl}^{-}$ & 0.168 & 7.66 & 2.65 & $0.14,0.2$ & 147 & 1 & $\mu \mathrm{g} \mathrm{m}^{-3}$ \\
\hline $\mathrm{EF}\left(\mathrm{Cl}^{-}\right)$ & 0.0723 & 0.763 & 0.447 & & 147 & & \\
\hline $\mathrm{Cl}^{-}$deficit & 1.31 & 6.53 & 2.96 & & 147 & & $\mu \mathrm{g} \mathrm{m}^{-3}$ \\
\hline $\mathrm{Br}^{-}$ & $<\mathrm{DL}$ & 16.7 & 4.59 & $1.3,8.2$ & 147 & 115 & $\mathrm{ng} \mathrm{m}^{-3}$ \\
\hline $\mathrm{EF}\left(\mathrm{Br}^{-}\right)$ & 0.0605 & 0.963 & 0.227 & & 147 & & \\
\hline $\mathrm{Br}^{-}$deficit & 0.404 & 40.2 & 14.3 & & 147 & & $\mathrm{ng} \mathrm{m}^{-3}$ \\
\hline $\mathrm{SO}_{4}^{2-}$ & 0.866 & 6.26 & 2.36 & $0.09,0.036$ & 147 & 0 & $\mu \mathrm{g} \mathrm{m}^{-3}$ \\
\hline $\mathrm{Na}^{+}$ & 1.11 & 7.91 & 3.2 & $0.069,0.14$ & 147 & 0 & $\mu \mathrm{g} \mathrm{m}^{-3}$ \\
\hline $\mathrm{NH}_{4}^{+}$ & $<\mathrm{DL}$ & 1.11 & 0.292 & $0.49,0.19$ & 147 & 51 & $\mu \mathrm{g} \mathrm{m}^{-3}$ \\
\hline $\mathrm{K}^{+}$ & $<\mathrm{DL}$ & 0.31 & 0.146 & $0.064,0.11$ & 147 & 32 & $\mu \mathrm{g} \mathrm{m}^{-3}$ \\
\hline $\mathrm{Mg}^{2+}$ & 0.143 & 0.979 & 0.418 & $0.046,0.006$ & 147 & 0 & $\mu \mathrm{g} \mathrm{m}^{-3}$ \\
\hline $\mathrm{Ca}^{2+}$ & $<\mathrm{DL}$ & 0.632 & 0.19 & $0.35,0.15$ & 147 & 59 & $\mu \mathrm{g} \mathrm{m}^{-3}$ \\
\hline
\end{tabular}

* For IC and for chloride from NAA, the blanks' analyses indicated two distinct subsets with quite different concentrations of several ions. Individual detection limits were calculated for these subsets.

and analyzed using procedures identical to those for samples. Between each use filter cassettes were completely disassembled, cleaned with dilute Liquinox solution, rinsed with DIW and dried in a clean bench. Exposed filters were transferred to clean polyethylene envelopes, frozen, and transported to and stored frozen at the University of New Hampshire (UNH) prior to preparation for analysis.

Using tandem impregnated filters allowed to calculate the collection efficiency $\varepsilon$ for volatile inorganic bromine $\mathrm{Br}_{\mathrm{g}}$ :

$\varepsilon=\frac{m_{1}}{m_{\mathrm{tot}}}=\frac{m_{2}}{\left(m_{\mathrm{tot}}-m_{1}\right)}$.

Here, $m_{1}$ and $m_{2}$ are the masses deposited on the first and second impregnated filter, respectively, and $m_{\text {tot }}$ is the total mass that would be deposited at $100 \%$ collection efficiency. Rearranging the equations and inserting the known values of $m_{1}$ and $m_{2}$ yields a collection efficiency of

$\varepsilon=1-m_{2} / m_{1}$

and a total mass of

$m_{\mathrm{tot}}=\frac{m_{1}}{1-m_{2} / m_{1}}$.

All filters were analyzed by neutron activation analysis (NAA) using a procedure based on that described by Uematsu et al. (1983). Standards were prepared by spotting aliquots of a NIST-traceable mixed element standard solution (Ultra Scientific, North Kingstown, RI) on blank filter circles. Standards, samples and field blanks were each 

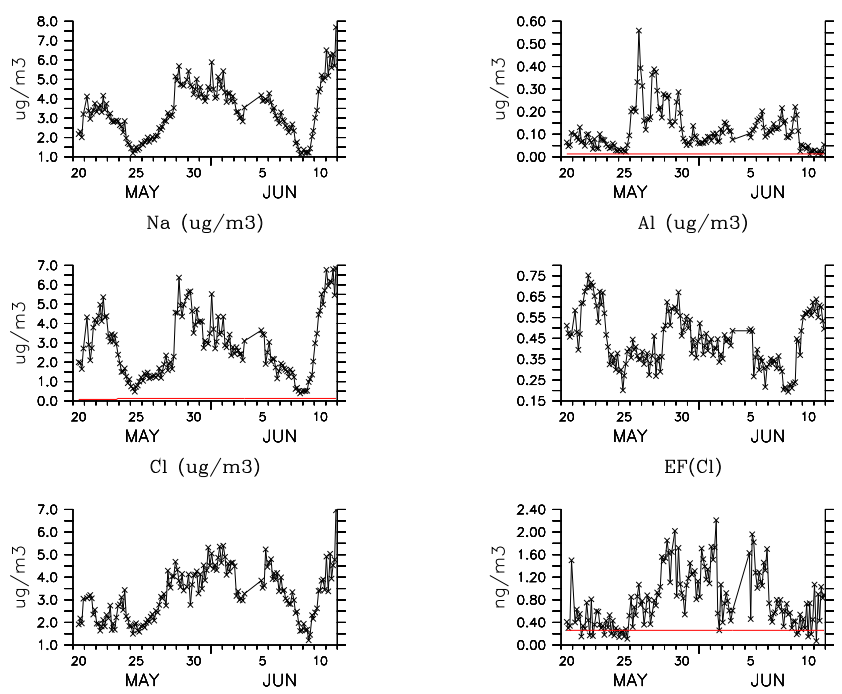

$\mathrm{Cl}$ deficit (ug/m3)
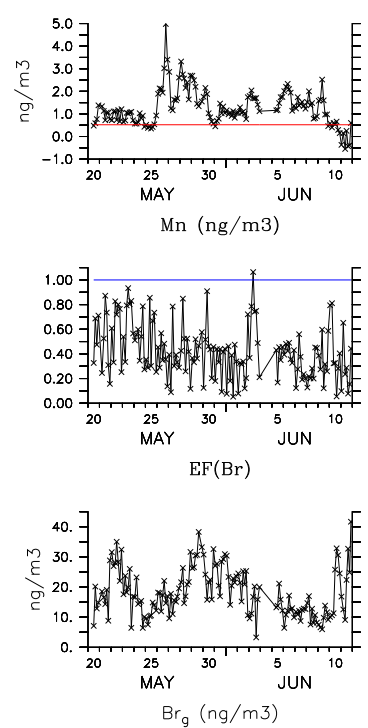

Figure 6. Time series of the filter pack data, analyzed by NAA. The red lines denote the detection limit and the blue lines denote sea water composition, i.e., $\mathrm{EF}=1$ and deficit $=0$.

spiked with $20 \mathrm{ng}$ of indium in dilute nitric acid (as an aliquot of a NIST-traceable standard solution; Ultra Scientific) as internal flux monitor, sealed in a clean polyethylene envelope and subsequently irradiated at the Rhode Island $\mathrm{Nu}-$ clear Science Center (RINSC) for $300 \mathrm{~s}$ at a nominal flux of $4 \times 10^{12} \mathrm{~cm}^{-2} \mathrm{~s}^{-1}$ thermal neutrons. Following irradiation, samples were allowed to decay for approximately $5 \mathrm{~min}$ during which they were transferred to non-irradiated envelopes, and counted for $900 \mathrm{~s}$ live time on a $\mathrm{Ge}(\mathrm{Li})$ gamma-ray spectrometer. From the particle filters, data were obtained for six elements: $\mathrm{Na}, \mathrm{Al}, \mathrm{Cl}, \mathrm{Mn}, \mathrm{V}$, and Br. Using Eq. (3), gaseous $\mathrm{Br}$ data were obtained from the impregnated filters. All laboratory manipulations of cassettes and filters prior to irradia- tion were carried out in class 100 clean benches by personnel wearing unpowdered plastic gloves.

About three years after the NAA analysis, the radioactivity had decreased to a safe level, and it was possible to handle the samples again. The aerosols on the particle filters were extracted under sonication in DIW. The ionic species $\mathrm{SO}_{4}^{2-}$, $\mathrm{Cl}^{-}, \mathrm{Br}^{-}, \mathrm{NH}_{4}^{+}, \mathrm{Na}^{+}, \mathrm{K}^{+}, \mathrm{Mg}^{2+}$, and $\mathrm{Ca}^{2+}$ were determined by high-performance ion chromatography (IC) using procedures similar to those described by Keene et al. (2009). Data for samples were corrected based on median concentrations of analytes recovered from handling blanks $(n=10)$.

To estimate the detection limits for the filter pack aerosol samples, we used Eq. (14) of Currie (1995). An element or ion was deemed detected if its mass (NAA) or extract concentration (IC) exceeded its minimal detectable value estimated via

$\mathrm{DL}=2 t_{1-\alpha, \nu} s_{0}$,

where DL is the detection limit (minimal detectable value), $t$ is the value of Student's $t$ statistic for probability level $\alpha$ and $v$ degrees of freedom (i.e., number of blanks), and $s_{0}$ is the standard deviation of mass or concentration values determined in the $N$ blanks analyzed. The choice of $\alpha=0.025$ corresponds to rejecting a null hypothesis of "not detected" at the $95 \%$ confidence level. The average sampled air volume for all samples of $12.4 \mathrm{~m}^{3} \mathrm{STP}\left(0^{\circ} \mathrm{C}, 1 \mathrm{~atm}\right)$ was assumed for all calculations.

For IC, the blanks' analyses indicated two distinct subsets of blanks of $N=3$ and $N=20$, respectively, with quite different concentrations of several ions. For NAA, chlorine appeared to have the same two subsets. For other elements determined no distinct subsets were apparent.

The phase partitioning of $\mathrm{HCl}$ and $\mathrm{NH}_{3}$ with aerosol solutions is $\mathrm{pH}$ dependent, and aerosol $\mathrm{pH}$ typically varies as a function of size. Because the $\mathrm{pH}$ of aerosols sampled in bulk on a filter may diverge from the $\mathrm{pH}$ of the aerosol size fractions with which most $\mathrm{Cl}^{-}$and $\mathrm{NH}_{4}^{+}$is associated in ambient air, these species are subject to artifact phase changes when sampled in bulk (e.g., Keene et al., 1990). Consequently, the absolute concentrations and associated enrichment factors and deficits relative to sea salt that are reported herein may not be representative of those for ambient aerosols during the campaign.

\section{Data summary}

A detailed analysis of the data is beyond the scope of a paper in this journal. Here, we only present the data and draw some basic conclusions. Table 1 lists minimum, maximum, average, and median values, and Figs. 6, 7, and 8 show time series of the measurements.

Regarding the analytical techniques applied here, we found very good correlations between $\mathrm{Na}$ and $\mathrm{Cl}$ measured by NAA vs. IC (Fig. 10) coupled with slopes and intercepts 

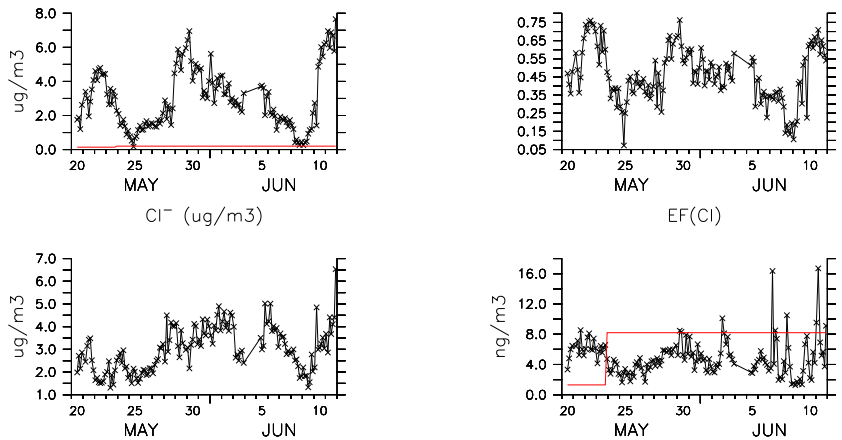

$\mathrm{Cl}$ deficit (ug/m3)
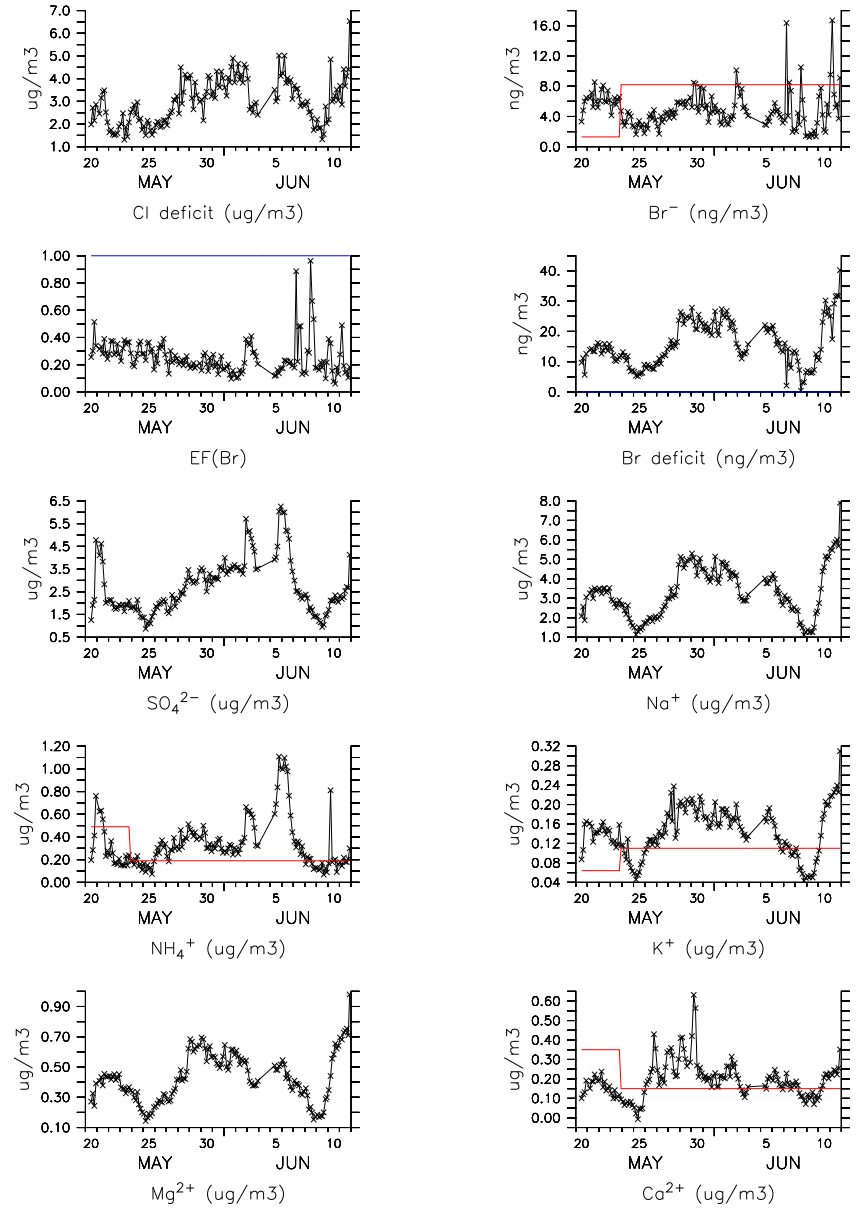
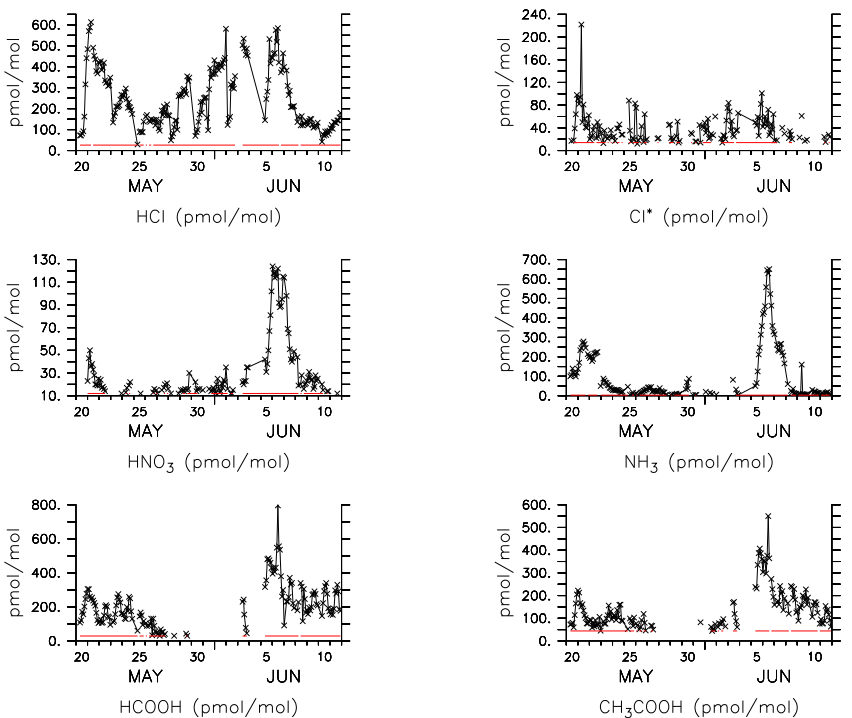

Figure 8. Time series of the mist chamber data. $\mathrm{Cl}^{*}$ denotes reactive chlorine. The red lines denote the detection limit.
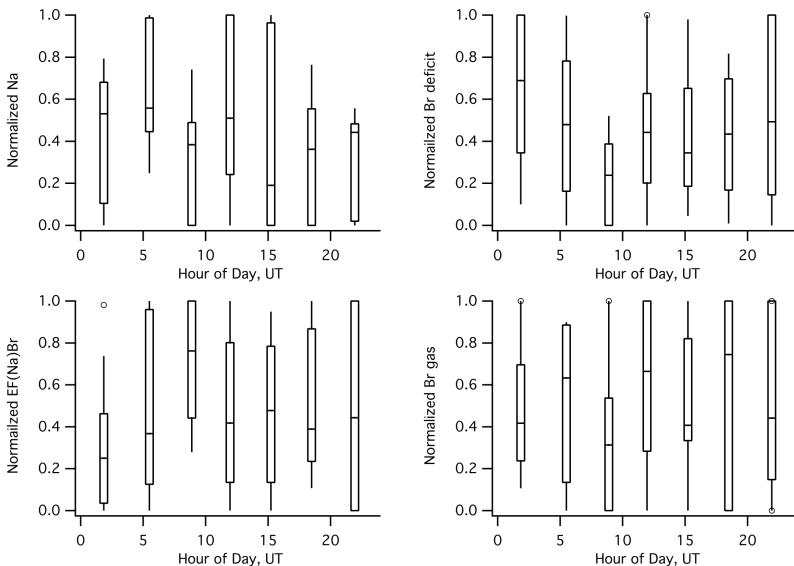

Figure 9. Box-and-whisker plots of the diel variability of normalized $\mathrm{Na}$ and $\mathrm{Br}$ data. In these plots the daily maximum concentration was set to 1 and the minimum concentration was set to 0 . The solid line near the middle of each box represents the median. The bottom of the box represents the 25th percentile and the top of the box represents the 75 th percentile. The whisker ends mark the 10th and 90th percentiles. Outliers are displayed for values below the 1st or above the 99th percentile.

that are statistically indistinguishable from 1.0 and 0.0 , respectively. This indicates that (1) virtually all particulate $\mathrm{Na}$ and $\mathrm{Cl}$ were in the forms $\mathrm{Na}^{+}$and $\mathrm{Cl}^{-}$, respectively, and (2) $\mathrm{Na}^{+}$and $\mathrm{Cl}^{-}$in samples did not deteriorate while stored for $3 \mathrm{yr}$.

Correlations between selected data are shown in Fig. 10. A good correlation can indicate a common origin. The relative concentrations of $\mathrm{Na}, \mathrm{Mg}$ and $\mathrm{K}$ are the same as for sea salt. The correlation between $\mathrm{Al}$ and $\mathrm{Mn}$ points towards crustal dust. The presence of volatile acids at detectable mixing ratios indicates that aerosols were either acidic or rapidly acidified throughout the campaign. A good correlation be- tween the acids $\mathrm{HCOOH}$ and $\mathrm{CH}_{3} \mathrm{COOH}$ (Fig. 10) suggests common sources and/or processing.

In the context of reactive halogens, the main focus of the campaign, a few definitions are needed for the evaluation of the results. Adopting the equations from Sander et al. (2003) and using the seawater mass ratios $([\mathrm{Cl}] /[\mathrm{Na}])_{\text {seawater }}=$ $1.8 \mathrm{~kg} \mathrm{~kg}^{-1}$ and $([\mathrm{Br}] /[\mathrm{Na}])_{\text {seawater }}=0.0062 \mathrm{~kg} \mathrm{~kg}^{-1}$, we define the enrichment factors $\mathrm{EF}(\mathrm{X})$ for $\mathrm{X}=\mathrm{Cl}$ and $\mathrm{Br}$ as 

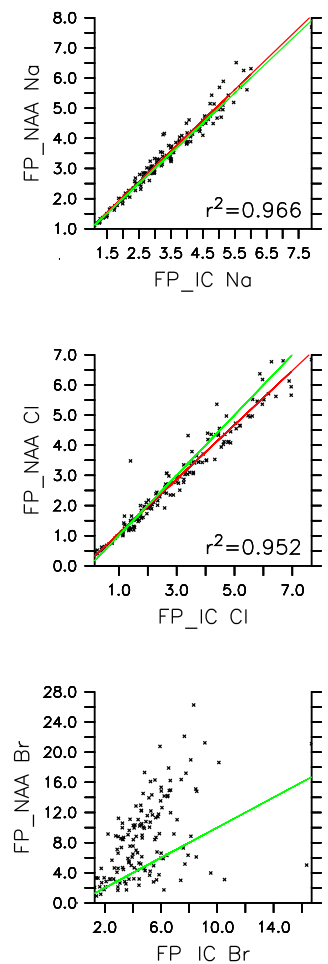
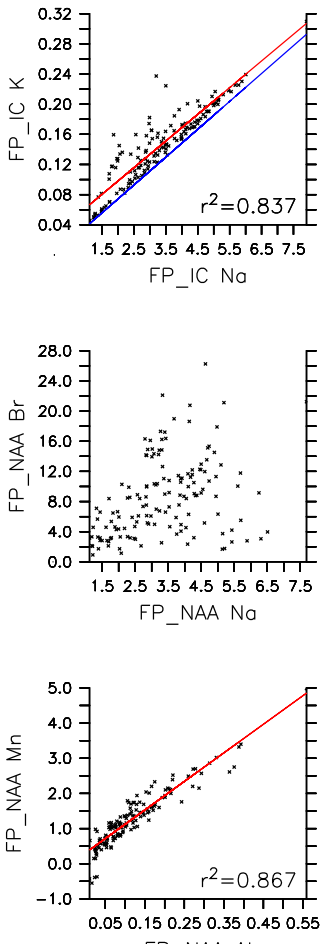

FP_NAA Al
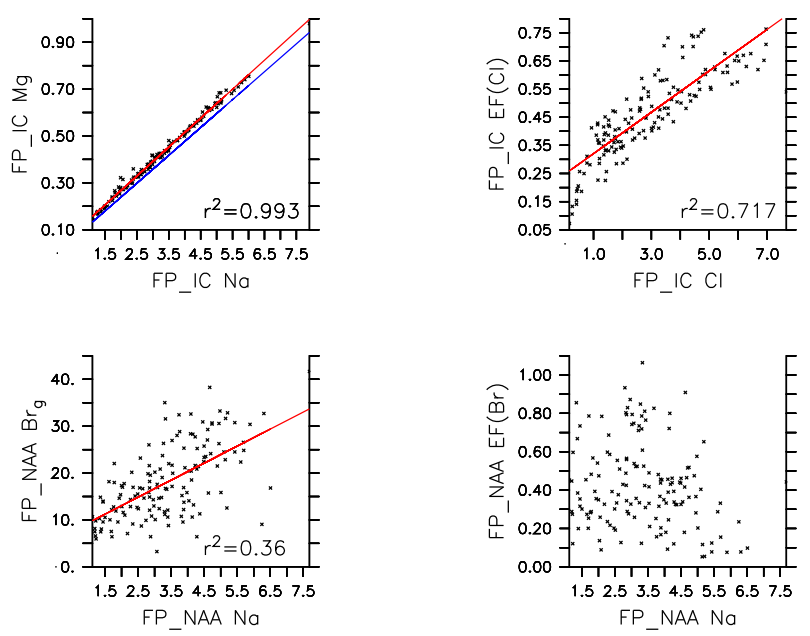

FP_NAA No

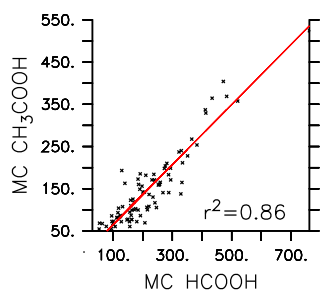

Figure 10. Scatter plots. The first column shows comparisons between filter pack samples analyzed by neutron activation (prefix FP_NAA) and ion chromatography (prefix FP_IC), respectively, with a $1: 1$ line in green. The second and third columns show correlations between selected data, where the prefix MC refers to mist chamber data, and a blue line indicates the sea water composition. Finally, the last column shows correlations to the derived quantities enrichment factor and deficit, as defined in Sect. 4. The units of all plots are the same as listed in Table 1. Regression lines in red are only shown if $r^{2}>0.3$.

$\mathrm{EF}(\mathrm{X})=\frac{[\mathrm{X}] /[\mathrm{Na}]}{([\mathrm{X}] /[\mathrm{Na}])_{\text {seawater }}}$

where square brackets denote mass concentrations. Another useful quantity is the absolute deficit, which is defined as

deficit $=\left[[\mathrm{Na}] \times\left(\frac{[\mathrm{X}]}{[\mathrm{Na}]}\right)_{\text {seawater }}\right]-[\mathrm{X}]$.

We also define the quantity $\Delta \mathrm{Br}$, which is the difference between gas-phase bromine and the bromine deficit. The following are our main conclusions regarding measured halogens.

- Values for total bromine analyzed by NAA are higher than those for bromide analyzed by IC. This indicates that some aerosol bromine is in a form other than $\mathrm{Br}^{-}$.

- $\mathrm{EF}(\mathrm{Br})$ was not correlated with particulate $\mathrm{Na}^{+}$. Absolute deficits of particulate $\mathrm{Br}$ and mixing ratios of gasphase bromine $\left(\mathrm{Br}_{\mathrm{g}}\right)$ increased with increasing sea-salt concentrations. These relationships together with the presence of acidic gases at detectable levels indicate that sufficient acidity was available to titrate sea-salt alkalinity and sustain halogen activation over the full range of sea-salt loadings during the experiment.
- $\mathrm{Br}_{\mathrm{g}}$ concentrations are almost always higher than absolute deficits of particulate $\mathrm{Br}$ (the difference is shown as "delta Br" in Fig. 6). This implies that $\mathrm{Br}_{\mathrm{g}}$ has a longer atmospheric lifetime than the parent aerosol. This has also been observed in a previous campaign (Keene et al., 2009).

- Systematic diel variability was not evident in either the aerosol $\mathrm{Br}$ enrichment factor nor inorganic gaseous $\mathrm{Br}$ (Fig. 9). This is in contrast to previous measurements in the MBL at Hawaii (Sander et al., 2003) and over the eastern Atlantic (Keene et al., 2009).

\section{Supplementary material related to this article is available online at http://www.earth-syst-sci-data.net/5/ 385/2013/essd-5-385-2013-supplement.zip.}

Acknowledgements. We thank B. Faria (Instituto Nacional de Meteorologia e Geofísica, São Vicente) and technical staff at the Cape Verde Atmospheric Observatory for outstanding logistical support. K. Read, J. Plane, D. Heard, G. McFiggans, L. Carpenter, E. Saltzman and their respective students and staff collaborated in 
the research effort. This research was funded by the US National Science Foundation via awards AGS-0646864 to the University of New Hampshire, and AGS-0646854 and AGS-0541570 to the University of Virginia.

Edited by: V. Sinha

\section{References}

Allan, J. D., Topping, D. O., Good, N., Irwin, M., Flynn, M., Williams, P. I., Coe, H., Baker, A. R., Martino, M., Niedermeier, N., Wiedensohler, A., Lehmann, S., Müller, K., Herrmann, H., and McFiggans, G.: Composition and properties of atmospheric particles in the eastern Atlantic and impacts on gas phase uptake rates, Atmos. Chem. Phys., 9, 9299-9314, doi:10.5194/acp9-9299-2009, 2009.

Currie, L. A.: Nomenclature in evaluation of analytical methods including detection and quantification capabilities, Pure Appl. Chem., 67, 1699-1723, 1995.

Keene, W. C., Talbot, R. W., Andreae, M. O., Beecher, K., Berresheim, H., Castro, M., Farmer, J. C., Galloway, J. N., Hoffmann, M. R., Li, S.-M., Maben, J. R., Munger, J. W., Norton, R. B., Pszenny, A. A. P., Puxbaum, H., Westberg, H., and Winiwarter, W.: An intercomparison of measurement systems for vapor and particulate phase concentrations of formic and acetic acids, J. Geophys. Res., 94D, 6457-6471, 1989.

Keene, W. C., Pszenny, A. A. P., Jacob, D. J., Duce, R. A., Galloway, J. N., Schultz-Tokos, J. J., Sievering, H., and Boatman, J. F.: The geochemical cycle of reactive chlorine through the marine troposphere, Global Biogeochem. Cycles, 4, 407-430, 1990.

Keene, W. C., Maben, J. R., Pszenny, A., and Galloway, J. N.: Measurement technique for inorganic chlorine gases in the marine boundary layer, Environ. Sci. Technol., 27, 866-874, 1993.

Keene, W. C., Long, M. S., Pszenny, A. A. P., Sander, R., Maben, J. R., Wall, A. J., O'Halloran, T. L., Kerkweg, A., Fischer, E. V., and Schrems, O.: Latitudinal variation in the multiphase chemical processing of inorganic halogens and related species over the eastern North and South Atlantic Oceans, Atmos. Chem. Phys., 9, 7361-7385, doi:10.5194/acp-9-7361-2009, 2009.

Lawler, M. J., Finley, B. D., Keene, W. C., Pszenny, A. A. P., Read, K. A., von Glasow, R., and Saltzman, E. S.: Pollutionenhanced reactive chlorine chemistry in the eastern tropical Atlantic boundary layer, Geophys. Res. Lett., 36, L08810, doi:10.1029/2008GL036666, 2009.
Lee, J. D., Moller, S. J., Read, K. A., Lewis, A. C., Mendes, L., and Carpenter, L. J.: Year-round measurements of nitrogen oxides and ozone in the tropical North Atlantic marine boundary layer, J. Geophys. Res., 114D, D21302, doi:10.1029/2009JD011878, 2009.

Lee, J. D., McFiggans, G., Allan, J. D., Baker, A. R., Ball, S. M., Benton, A. K., Carpenter, L. J., Commane, R., Finley, B. D., Evans, M., Fuentes, E., Furneaux, K., Goddard, A., Good, N., Hamilton, J. F., Heard, D. E., Herrmann, H., Hollingsworth, A., Hopkins, J. R., Ingham, T., Irwin, M., Jones, C. E., Jones, R. L., Keene, W. C., Lawler, M. J., Lehmann, S., Lewis, A. C., Long, M. S., Mahajan, A., Methven, J., Moller, S. J., Müller, K., Müller, T., Niedermeier, N., O’Doherty, S., Oetjen, H., Plane, J. M. C., Pszenny, A. A. P., Read, K. A., Saiz-Lopez, A., Saltzman, E. S., Sander, R., von Glasow, R., Whalley, L., Wiedensohler, A., and Young, D.: Reactive Halogens in the Marine Boundary Layer (RHaMBLe): the tropical North Atlantic experiments, Atmos. Chem. Phys., 10, 1031-1055, doi:10.5194/acp-10-10312010, 2010.

Maben, J. R., Keene, W. C., Pszenny, A. A. P., and Galloway, J. N.: Volatile inorganic $\mathrm{Cl}$ in surface air over eastern North America, Geophys. Res. Lett., 22, 3513-3516, 1995.

Rahn, K. A., Borys, R. D., and Duce, R. A.: Tropospheric halogen gases: Inorganic and organic components, Science, 192, 549550, 1976.

Read, K. A., Mahajan, A. S., Carpenter, L. J., Evans, M. J., Faria, B. V. E., Heard, D. E., Hopkins, J. R., Lee, J. D., Moller, S. J., Lewis, A. C., Mendes, L., McQuaid, J. B., Oetjen, H., Saiz-Lopez, A., Pilling, M. J., and Plane, J. M. C.: Extensive halogen-mediated ozone destruction over the tropical Atlantic Ocean, Nature, 453, 1232-1235, 2008.

Sander, R., Keene, W. C., Pszenny, A. A. P., Arimoto, R., Ayers, G. P., Baboukas, E., Cainey, J. M., Crutzen, P. J., Duce, R. A., Hönninger, G., Huebert, B. J., Maenhaut, W., Mihalopoulos, N., Turekian, V. C., and Van Dingenen, R.: Inorganic bromine in the marine boundary layer: a critical review, Atmos. Chem. Phys., 3, 1301-1336, doi:10.5194/acp-3-1301-2003, 2003.

Uematsu, M., Duce, R. A., Prospero, J. M., Chen, L., Merrill, J. T., and McDonald, R. L.: Transport of mineral aerosol from Asia over the North Pacific Ocean, J. Geophys. Res., 88C, 5343-5352, 1983. 